\title{
Binding of Extracellular Matrix Molecules by Staphylococci from Wild Herbivores
}

\author{
I. ŠTYRIAK, A. LAUKOVÁ, Å. LJUNGH*
}

Institute of Animal Physiology, Slovak Academy of Sciences, Košice, Slovak Republic *Department of Medical Microbiology, Dermatology and Infection, Lund University, Lund, Sweden

\author{
Received February 18, 2002 \\ Accepted June 19, 2002
}

\section{Abstract}

Štyriak I., A. Lauková, Å. Ljungh: Binding of Extracellular Matrix Molecules by Staphylococci from Wild Herbivores. Acta Vet. Brno 2002, 71: 369-374.

Nine strains of staphylococci were examined for their antibiotic resistance and for binding of seven extracellular matrix (ECM) molecules (bovine mucin, porcine mucin, porcine fibronectin, bovine fibrinogen, fetuin, bovine lactoferrin and heparin) immobilized on latex beads in the particle agglutination assay.

All nine strains were resistant to bacitracin, and most of them were multiresistant. Four strains displayed resistance to 5 of 13 antibiotics tested. Different binding capability between individual strains was observed. There were strains binding several ECM molecules (as S. warneri SW6 and $S$. epidermidis SE14) as well as strains which bound only one (S. aureus SA11) or no ECM molecule ( $S$. saprophyticus SS16) of seven tested. While some ECM molecules, e.g. porcine fibronectin and heparin, were bound by most of strains, others (e.g. mucins) were bound only by 1 or 2 strains. Some strains bound these substrates weakly, however, other strains displayed strong binding especially of heparin and porcine fibronectin.

The preincubation of bacteria for 1 hour at room temperature with a protein used subsequently in the PAA completely prevented the agglutination reaction, thus indicating the specificity of the assay.

ECM binding, mucin, fibronectin, fibrinogen, fetuin, heparin, lactoferrin, antibiotic resistance,

Bacterial pathogens commonly adhere to host tissues as a first step in the pathogenic process of many infectious diseases. Following epithelial trauma, these pathogens may interact with various subepithelial extracellular matrix (ECM) structures (Ljungh and Wadström 1995). This bacterial adherence is mediated primarily by adhesins on the bacterial surface which bind specifically to complimentary ligands (Höök et al. 1990). The ECM is composed of glycoproteins and glycosaminoglycans which form a network by means of a number of specific interactions between different ECM components (Ljungh et al. 1996). Since most ECM are covered by epithelial or endothelial cells, they are not available for bacterial binding. However, damaged tissue surface may expose ECM and allow microbial colonization and infection (Ljungh and Wadström 1995). In recent years, binding of several ECM proteins by many Gram positive cocci (including staphylococci) has been investigated. Despite the fact that only a few bacterial species have been proven to use the ability to bind an ECM protein as a virulence determinant (Lowrance et al. 1990; Patti et al. 1994; Hienz et al. 1996), this property may be involved in the pathogenicity of several bacterial species (Naidu et al. 1988; Ljungh and Wadström 1995).

While some staphylococci display high virulence, others may have a commensal relationship with their host. Generally, staphylococci form an important component of the bacterial community in the rumen content as well as on the rumen wall of domestic and wild ruminants (Wallace et al. 1979; Fonty et al. 1984; Kmet et al. 1990; Lauková 1994). Despite the fact that staphylococci are known also as lactic acid producers and belong

Address for correspondence:

Dr. Igor Štyriak, Ph. D.

Institute of Animal Physiology SAS

04001 Košice, Slovakia
Phone: +42155633625

Fax: +42155678 2162

http://www.vfu.cz/acta-vet/actavet.htm 
together with lactobacilli and enterococci to the first bacterial groups colonizing the rumen of young ruminants (Lauková 1994), they may be important in causing infection under the appropriate predisposing conditions similar to those described by Jett et al. (1994) for enterococci.

The aim of the present study was to determine the ability of 9 selected staphylococcal strains originally isolated from rumen content of mouflons and European bison to bind some ECM molecules immobilised on latex beads by rapid PAA (particle agglutination assay), and to compare results obtained with previously investigated animal staphylococci (Štyriak et al. 1999a).

The extension of our results is in the examination of bacterial resistance to 13 antibiotics. This fact is interesting because especially multiresistant strains could complicate a usual antibiotic therapy in case of infection.

\section{Materials and Methods}

Sources and cultivation of strains

Nine strains of staphylococci from the bacterial collection of Dr. Lauková originally isolated from rumen content of wild herbivores (seven isolates from rumen of mouflons and two from European bison, ZOO Košice) were used together with 5 control strains from the collection of the Medical Microbiology Department at Lund University in our assay. The strain Helicobacter pylori NCTC 11637 was used as positive control for fetuin and mucin binding (Lelwala-Guruge et al. 1993) and 4 staphylococcal strains (Staphylococcus aureus Cowan1, S. saprophyticus TW111, S. haemolyticus SM 131 and Staphylococcus sp. LS1) as controls for the binding of the other ECM molecules. Staphylococci were cultivated using blood agar plates (Difco, Detroit, MI) with 5\% horse erythrocytes overnight at $37{ }^{\circ} \mathrm{C}$ and H.pylori NCTC 11637 on GAB-CAMP agar (blood agar supplemented with 5\% saponin lysed equine erythrocytes) under microaerophilic conditions $\left(5 \% \mathrm{O}_{2}, 10 \% \mathrm{CO}_{2}, 85 \% \mathrm{~N}_{2}\right)$ at $37{ }^{\circ} \mathrm{C}$ for 2 to $3 \mathrm{~d}$. Ruminal staphylococci were phenotypically allotted by Becton-Dickinson identification system (Cockeysville, USA) to following species: Staphylococcus warneri, S. saprophyticus, S. epidermidis, S. xylosus, S. haemolyticus and S. aureus (Table 1). They are lactic acid producing and ureolytic bacteria (Lauková 1993).

Chemicals

Human serum albumin (HSA), bovine lactoferrin, fetuin, mucin type III (partially purified) from porcine stomach, piperazine N-N-bis-2-ethanolsulfonic acid, and EDAC (1-Ethyl 3-3-dimethylamino propyl carbodiimide hydrochloride) were purchased from Sigma Chemicals Co., St Louis (Missouri, USA). Citric acid and glycine were from Merck AG (Darmstadt, Germany). Heparin sodium salt was supplied from Fluka (Buchs, Switzerland), porcine plasma fibronectin was from BioInvent International AB (Lund, Sweden), bovine serum fibrinogen from Behring Diagnostics (La Jolla, CA, USA), mucin from bovine submaxillary glands from ICN Biomedicals Inc. (Aurora, Ohio, USA), merthiolate from Kabi AB (Stockholm, Sweden), latex beads $(0.81 \mu \mathrm{m}$ diameter) from Difco Laboratories, Detroit, (MI, USA), and carboxylated modified latex beads ( $0.55 \mu \mathrm{m}$ diameter) from Seradyn Inc. Particle Technol. Div., Indianapolis (Indiana, USA). All buffers and chemicals were of analytical grade.

Antibiotic resistance

Staphylococcal resistance to 13 antibiotics was tested by agar diffusion method using the following antibiotic disks (Becton and Dickinson, Cockeysville, USA): ampicillin $10 \mu \mathrm{g}$ (Amp), erythromycin $15 \mu \mathrm{g}$ (Eryth), fosfomycin $50 \mu \mathrm{g}$ (Fosf) gentamicin $10 \mu \mathrm{g}$ (Gent), chloramphenicol $30 \mu \mathrm{g}$ (CHC), bacitracin 2 units (Bac), kanamycin $30 \mu \mathrm{g}(\mathrm{Kan})$, lincomycin $10 \mu \mathrm{g}$ (Linc), methicilin $5 \mu \mathrm{g}$ (Met), novobiocin $30 \mu \mathrm{g}(\mathrm{NB})$, tetracycline 30 $\mu \mathrm{g}$ (TTC), vancomycin $30 \mu \mathrm{g}$ (Vanc), and rifampicin $30 \mu \mathrm{g}$ (Rif). Testing was performed on Columbia blood agar (Becton and Dickinson). Staphylococcus aureus CB44 (University of Veterinary and Pharmaceutical Sciences, Brno, Czech Republic) was used as a control organism.

Adsorption of ECM molecules to latex beads

The ECM molecules were adsorbed to the latex beads $(0.81 \mu \mathrm{m}$ diameter $)$ by electrostatic and hydrophobic interactions according to the method described earlier (Naidu et al. 1988; Śtyriak et al. 1999b).

Covalent coupling of fetuin and mucins to carboxylated modified latex beads

Hundred $\mu$ of carboxylated modified latex (CML) beads were washed twice with $0.1 \mathrm{M}$ phosphate buffer (pH 8.1) and were resuspended in $1 \mathrm{ml}$ of phosphate buffer ( $\mathrm{pH} 8.1$ ) containing $2 \mathrm{mg} / \mathrm{ml}$ EDAC (1-ethyl 3-3dimethylamino propyl carbodiimide hydrochloride). This solution was added to beads drop by drop and the mixtures were incubated overnight at $4{ }^{\circ} \mathrm{C}$ on a rotatory mixer. The suspensions were then centrifuged at $12000 \mathrm{~g}$ for $10 \mathrm{~min}$, suspended in $1 \mathrm{ml}$ of phosphate buffer containing $1 \mathrm{mg} / \mathrm{ml}$ protein, and then incubated overnight at $4{ }^{\circ} \mathrm{C}$ on a rotatory mixer. Latex beads were subsequently centrifuged at $12000 \mathrm{~g}$ for $10 \mathrm{~min}$, and the unbound protein 
in the supernatant fluids was determined. Finally, the protein-coated CML particles were resuspended in $1 \mathrm{ml}$ of phosphate buffer containing $0.01 \%$ merthiolate and stored at $4{ }^{\circ} \mathrm{C}$ until use in particle agglutination assay.

Particle agglutination assay (PAA)

The protein-coated latex beads $(20 \mu \mathrm{l})$ were mixed on a glass slide with an equal volume of a bacterial cell suspension of $10^{10} \mathrm{cfu}$ per $\mathrm{ml}$. These two drops were gently mixed and the agglutination reaction was scored after 2 min from strongly positive (3) to weakly positive (1) or negative (0) as previously described (Naidu et al. 1988; Štyriak et al. 1999a). All strains were tested for autoaggregation by mixing one drop of a bacterial suspension with one drop of potassium phosphate buffer. Control strains (as negative and positive controls) were always used in this assay.

Particle agglutination inhibition assay (PAIA)

PAA reactions were inhibited by preincubation of $100 \mu 1$ of ECM protein with an equal volume of bacterial suspension for $1 \mathrm{~h}$ at room temperature. After washing, the bacterial suspensions were mixed with the same proteincoated latex beads, and PAA values were scored as in standard PAA.

\section{Results}

All selected strains were resistant at least to one antibiotic. As shown in Table 1, all nine strains were resistant to bacitracin. However, most of them were multiresistant. Four strains, both isolates from European bison ( $S$. xylosus SX9 and S. warneri SW15) as well as two strains from mouflons (S. saprophyticus SS16 and S. epidermidis SE14), displayed resistance to 5 of 13 antibiotics tested. The resistance pattern is not similar in these strains. However, the resistance to methicillin ( 5 strains) and kanamycin (4 strains) was also often detected (Table 1). On the other hand, all strains were sensitive to chloramphenicol, vancomycin and rifampicin.

Table 1

Staphylococci isolated from rumen content of ruminants kept in ZOO Košice

\begin{tabular}{|l|l|l|}
\hline Strain & Source of isolation & Antibiotic resistance to \\
\hline S. warneri SW13 & Mouflon & Bac, Kan, Met \\
\hline S. aureus SA11 & Mouflon & Bac, Kan, Met \\
\hline S. saprophyticus SS16 & Mouflon & Fosf, Bac, Kan, Met, NB \\
\hline S. haemolyticus SF15 & Mouflon & Bac \\
\hline S. epidermidis SE14 & Mouflon & Amp, Eryth, Bac, Met, TTC \\
\hline S. warneri SW6 & Mouflon & Bac \\
\hline S. epidermidis SE9 & Mouflon & Bac \\
\hline S. xylosus SX9 & European bison & Fosf, Gent, Bac, Kan, Met \\
\hline S. warneri SW15 & European bison & Eryth, Fosf, Bac, Linc, Met \\
\hline
\end{tabular}

Legend:

Abbreviations of tested antibiotics:

ampicillin (Amp), erythromycin (Eryth), fosfomycin (Fosf) gentamicin (Gent), chloramphenicol (CHC), bacitracin (Bac), kanamycin (Kan), lincomycin (Linc), methicillin (Met), novobiocin (NB), tetracycline (TTC), vancomycin (Vanc), and rifampicin (Rif)

No autoaggregating strains were detected among nine selected staphylococci. Therefore they could be investigated for binding of seven different ECM molecules (bovine mucin, porcine mucin, porcine fibronectin, bovine fibrinogen, fetuin, bovine lactoferrin and heparin) immobilized on latex beads in the particle agglutination assay. As shown in Table 2, differences between individual strains were observed. There are strains with positive binding to several ECM molecules (as e.g. S. warneri SW6 and S. epidermidis SE14) as well as the strains which bound only one (S. aureus SA11) or no ECM molecule ( $S$. saprophyticus SS16) of seven tested. While some ECM molecules, e.g. porcine fibronectin and heparin, were bound by most of strains, other molecules (e.g. mucins) were bound only by 1 or 2 
Table 2

Binding of 7 ECM substrates by staphylococcal strains isolated from wild herbivores in ZOO after their cultivation on $\mathrm{TH}$ agar plates tested by PAA

\begin{tabular}{l|l|c|c|c|c|c|c|}
\hline Strain & BM & PM & PFIB & BFIB & FET & BLACT & HEP \\
\hline SW6 & 0 & 3 & 3 & 3 & 0 & 2 & 3 \\
\hline SW13 & 0 & 0 & 2 & 1 & 0 & 0 & 1 \\
\hline SF15 & 0 & 0 & 3 & 0 & 0 & 1 & 3 \\
\hline SS16 & 0 & 0 & 0 & 0 & 0 & 0 & 0 \\
\hline SA11 & 2 & 0 & 0 & 0 & 0 & 0 & 0 \\
\hline SE14 & 1 & 0 & 2 & 0 & 0 & 1 & 3 \\
\hline SE9 & 1 & 0 & 1 & 0 & 0 & 1 & 3 \\
\hline SX9 & 0 & 0 & 2 & 0 & 0 & 0 & 3 \\
\hline SW15 & 0 & 0 & 3 & 0 & 0 & 0 & 3 \\
\hline
\end{tabular}

strains. Some strains bound these substrates weakly (1 or 2 ), however, other strains displayed strong (3) binding especially to heparin and porcine fibronectin. Interestingly, fetuin also called "lectin screening" protein was never bound by any of the strains tested.

The specific binding of a protein in the PAA was confirmed by the PAIA with the same ECM protein. The preincubation of bacteria with a protein used subsequently in the PAA for 1 hour at room temperature completely prevented the agglutination reaction, thus indicating the specificity of the assay.

\section{Discussion}

Many bacterial strains (including staphylococci) resistant to diverse currently available antibiotics are regularly isolated from humans and several farm animals. Moreover, a high antibiotic resistance was recorded also in bacteria from wild animals (Lauková 1995; Lauková 1999). Concerning high antibiotic resistance in farm animal isolates, it should be a result of the variety of antibiotic use programs needed for animal therapy, disease prevention, and/or production enhancement (Gustafs on and Bowen 1997). However, multiresistant isolates from diverse farm and wild animals suggest that they could complicate conventional antibiotic therapy for veterinarians as well as for people in animal weaning because of possible transfer between humans and animals. This fact is supported by two studies of van den Bogaard et al. (1997ab) which indicate that humans and animals in close contact could harbour the same vancomycin-resistant strains.

As a consequence, there is an urgent need to seek an alternative to antibiotics for the purpose of enhancing the health status and production performance of domestic animals ( $\mathrm{J}$ in et al. 2000). Since sooner or later, the use of antimicrobials leads to the selection of resistant strains (Herrero et al. 2000). This role should be fulfiled by new vaccines on the basis of antibodies against ECM-binding proteins within targeting therapy as suggested by Lee (1998). This could be a future, useful alternative which could reduce the common antibiotic use in veterinary medicine.

In the current study, we examined some selected staphylococcal strains from mouflons and European bison for their antibiotic resistance and binding to ECM components.

As mentioned above and confirmed by our results, antibiotic resistance is widely distributed also in wild herbivores breeded in animal gardens. Bacitracin resistance could be the most widely distributed among the staphylococcal strains from rumen ingesta of wild 
herbivores. However, nine strains is too small a collection to permit general conclusions. There is a difference between the isolates from rumen of mouflons and European bisons with the predominant resistance to tetracycline (Lauková 1995) and bacitracin (this article) or enterococci isolated from faeces of wild herbivores when almost all strains were resistant to kanamycin (Štyriak et al. 2002).

The particle agglutination method, known as rapid assay for simple screening of bacterial isolates for serum and ECM protein binding, could be used because no autoaggregative strains were found among nine strains tested. As described above, individual strains showed different ECM binding patterns. The S. warneri SW6 strain displayed strong binding of four ECM molecules, however, bovine lactoferrin was bound a little weaker. Interestingly, this strain displayed only bacitracin resistance while $S$. saprophyticus SS16 with negative binding to seven ECM molecules expressed the resistance to five antibiotics. It is known that many of these binding interactions are dependent on the conformation of the ECM molecule as confirmed for fibronectin by Williams et al. (1982). However, we were able to examine the molecules only in immobilised form. It means that strains displaying negative binding of immobilised ECM molecules could bind some of them in soluble form like staphylococcal strains described previously (Štyriak et al. 1999a).

We would like to note in conclusion that the present short study suggest an importance of ECM binding investigation also in wild animal microflora because the presence of multiresistant strains able to bind several ECM molecules could be dangerous not only for the host animals in case of surface tissue (epithelium or endothelium) integrity disturbance but also for humans in close contact with these animals. That is why it should be followed by isolation and characterization of cell surface components responsible for ECM binding properties from the strains displaying the best binding activity.

\section{Väzba stafylokokov z divokých bylinožravcov $\mathbf{k}$ molekulám extracelulárnej matrix}

U deviatich kmeňov Staphylococcus sp. izolovaných z divokých bylinožravcov bola testovaná rezistencia na antibiotiká a ich schopnost väzby $\mathrm{k}$ siedmym rozličným molekulám extracelulárnej matrix (bovinnému mucínu, prasačiemu mucínu, prasačiemu fibronektínu, bovinnému fibrinogénu, fetuínu, bovinnému laktoferínu a heparínu) imobilizovaným na povrchu latexových guličiek pomocou rýchleho aglutinačného testu.

Všetkých devät testovaných kmeňov bolo rezistentných na bacitracín. Avšak väčšinou sa jednalo o multirezistentné kmene, z ktorých štyri sú rezistentné až k 5 z 13 testovaných antibiotík. Tieto kmene vykazovali rozdielnu väzobnú schopnost́. Niektoré z nich boli schopné viazat sa k viacerým molekulám ECM (ako S. warneri SW6 a S. epidermidis SE14), iné zasa adherovali len k jednej ( $S$. aureus SA11) alebo žiadnej ECM molekule $(S$. saprophyticus SS16) zo siedmych testovaných. Kým niektoré molekuly extracelulárnej matrix, napr. prasačí fibronektín a heparín, sa ukázali ako vhodné receptory pre väčšinu z 9 testovaných kmeňov, k iným molekulám (napr. mucínom) adherovali len 1 alebo 2 kmene. $\mathrm{K}$ niektorým molekulám, ako napr. $\mathrm{k}$ heparínu a prasačiemu fibronektínu, sa viazali baktérie vo väčších počtoch, kým $\mathrm{k}$ iným len $\mathrm{v}$ menších počtoch.

Špecificita tohto aglutinačného testu bola potvrdená tým, že po 1-hodinovej inkubácii s príslušným ECM proteínom, tento obsadil príslušné väzobné miesta na bakteriálnom povrchu a v následnom aglutinačnom teste vykázal bakteriálny kmeň negatívny výsledok pri aglutinácii s touto molekulou.

\section{Acknowledgements}

This study was supported by VEGA Grant 2/2043/22 from the Slovak Academy of Sciences and by the grant from the Swedish Medical Research Council (B95-6X-11229). 


\section{References}

FONTY, G, JOUANY, JP, SENAUD, J, GONET, P, GRAIN, J 1984: The evolution of microflora, microfauna and digestion in the rumen of lambs from birth to 4 months. Can J Anim Sci 64 (Suppl): 165-166

GUSTAFSON, RH, BOWEN, RE 1997: Antibiotic use in animal agriculture. J Appl Microbiol 83: 531-541

HERRERO, IA, TESHAGER, T, GARDE, J, MORENO, MA, DOMINGUEZ, L 2000: Prevalence of vancomycinresistant Enterococcus faecium (VREF) in pig faeces from slaughterhouses in Spain. Prev Vet Med 47: 255-262

HIENZ, SA, SCHENNINGS, T, HEIMDAHL, A, FLOCK, JI 1996: Collagen binding of Staphylococcus aureus is a virulence factor in experimental endocarditis. J Infect Dis 174: 83-88

HÖÖK, M, McGAVIN, MJ, SWITALSKI, LM, RAJA, R, RAUCCI, G, LINDGREN, P, LINDBERG, M, SIGNAS, C 1990: Interaction of bacteria with extracellular matrix proteins. Cell Differ Dev 32: 433-438

JETT, BD, HUYCKE, MM, GILMORE, MS 1994: Virulence of enterococci. Clin Microbiol Rev 7: 462-478

JIN, LZ, MARQUARDT, RR, ZHAO, X 2000: A strain of Enterococcus faecium (18C23) inhibits adhesion of enterotoxigenic Escherichia coli K88 to porcine small intestine mucus. Appl Environ Microbiol 66: 4200-4204

KMEŤ, V, BARAN, M, KALACHNYUK, GI: Influence of ruminal ecosystem of calves and lambs by microbial preparations (in Slovak). Ed: Veda, 1990, pp. 5-111

LAUKOVÁ, A 1993: The species representation of staphylococcus in rumen ingesta of mouflons and European bisons. Živočíšna Výroba 38: 139-143

LAUKOVÁ, A. 1994: Staphylococci associated with the rumen of young and wild ruminants. Lett Appl Microbiol 19: $26-27$

LAUKOVÁ, A 1995: Characteristics of streptococci and enterococci isolated from rumen of mouflons and European bisons. AJAS 8: $37-41$

LAUKOVÁ, A 1999: Vancomycin-resistant enterococci isolates from the rumen content of deer. Microbios 97: 95-101

LEE, JC 1998: An experimental vaccine that targets staphylococcal virulence. Trends Microbiol 6: 461- 463

LJUNGH, A, WADSTRÖM, T 1995: Binding of extracellular matrix proteins by microbes. Methods Enzymol 253 : 501-514

LJUNGH, A, MORAN, AP, WADSTRÖM, T 1996: Interactions of bacterial adhesins with extracellular matrix and plasma proteins: Pathogenic implications and therapeutic possibilities. FEMS Immunol Med Microbiol 16: $117-126$

LELWALA-GURUGE, J, ASCENCIO, F, KREGER, AS, LJUNGH, A, WADSTRÖM, T 1993: Isolation of a sialic acid-specific haemagglutinin of Helicobacter pylori strain NCTC 11637. Zbl Bakt 280: 93-106

LOWRANCE, JH, BADDOUR, LM, SIMPSON, WA 1990: The role of fibronectin binding in the rat model of experimental endocarditis caused by Streptococcus sanguis. J Clin Invest 86: 7-13

NAIDU, AS, PAULSSON, M, WADSTRÖM, T 1988: Particle agglutination assays for rapid detection of fibronectin, fibrinogen, and collagen receptors on Staphylococcus aureus. J Clin Microbiol 26: 1549-1554

PATTI, JM, BREMELL, T, KRAJEWSKA-PIETRASIK, D, ABDELNOUR, A, TARKOWSKI, T, RYDÉN, C, HÖÖK, M 1994: The Staphylococcus aureus collagen adhesin is a virulence determinant in experimental septic arthritis. Infect Immun 62: 152-161

ŠTYRIAK, I, LAUKOVÁ, A, FALLGREN, C, WADSTRÖM, T 1999a: Binding of extracellular matrix proteins by animal strains of staphylococcal species. Vet Microbiol 67: 99-112

ŠTYRIAK, I, LAUKOVÂ, A, FALLGREN, C, WADSTRÖM, T 1999b: Binding of selected extracellular matrix proteins to Enterococci and Streptococcus bovis of animal origin. Curr Microbiol 39: 327-335

ŠTYRIAK, I, LAUKOVÁ, A, FALLGREN, C, WADSTRÖM, T, LJUNGH, A 2002: Lectin-like binding and antibiotic sensitivity of enterococci from wild herbivores. Microbiol Res, in press

VAN DEN BOGAARD, AE, JENSEN, LB, STOBBERINGH, EE 1997a: Vancomycin-resistant enterococci in turkeys and farmers. N Engl J Med 337: 1558-1559

VAN DEN BOGAARD, AE, MERTENS, P, LONDON, NH, STOBBERINGH, EE 1997b: High prevalence of colonization with vancomycin- and pristinamycin resistant enterococci in healthy humans and pigs in the Netherlands: is the addition of antibiotics to animal feeds to blame? J Antimicrob Chemother 40: 454-456

WALLACE, RJ, CHENG, KJ, DINSDALE, D, ORSKOV, ER 1979: An independent microbial flora of the epithelium and its role in the ecomicrobiology of the rumen. Nature 279: 424-426

WILLIAMS, EC, JANMEY, PA, FERRY, JD, MOSHER, DF 1982: Conformational states of fibronectin. J Biol Chem 257: 14973-14978 